\title{
POLYPRENOL LIPOSOMES IMPROVE THE EFFICIENCY OF OXYGEN USAGE IN WELL-TRAINED AMATEUR ATHLETES
}

\author{
Laila Ušacka $^{1, \#}$, Līga Plakane ${ }^{2}$, Ilona Vanaga ${ }^{1,3,4}$, Kārlis Klētnieks ${ }^{5}$, Baiba Jansone ${ }^{1}$, \\ Ruta Muceniece ${ }^{1}$, Uǵis Klētnieks $^{5}$, and Leonora Pahirko ${ }^{6}$ \\ ${ }^{1}$ Faculty of Medicine, University of Latvia, 19 Raina Blvd, Rīga, LV-1586, LATVIA \\ ${ }^{2}$ Faculty of Biology, University of Latvia, 1 Jelgavas Str., Rīga, LV-1004, LATVIA \\ ${ }^{3}$ SIA "Silv EXPO", 12 Alberta Str., Rīga, LV-1010, LATVI \\ ${ }^{4}$ Rīga East University Hospital, Rīga, LATVIA \\ 5 Rīga Stradiṇš University, Rīga, LATVIA \\ 6 Faculty of Physics, Mathematics and Optometry, University of Latvia, 3 Jelgavas Str., Rīga, LV-1004, LATVIA \\ \# Corresponding author, laila.plakane@gmail.com
}

Contributed by Ruta Muceniece

\begin{abstract}
Polyprenols are natural substances that are known for their role as cell membrane protectors from peroxidation. However, there is a lack of information about their effect on the performance of athletes. Therefore, we studied the effects of polyprenol on athlete performance. A total of 30 male floorball players participated in this study, 16 of whom were taking $30 \mathrm{mg}$ polyprenol liposome caps and 14 of whom were not. All of the participants underwent $\mathrm{VO}_{2}$ max exhaustive incremental cycling testing, before and after the use of polyprenols. VO2peak and other cardiorespiratory variables were measured to evaluate cardiorespiratory adaptation. For the polyprenol users (PU) the oxygen pulse $\left(\mathrm{O}_{2} / \mathrm{HR}\right)$ increased by $0.9 \mathrm{ml} / \mathrm{beat}$, while in the control group $(\mathrm{C})$ decreased by 0.4 $\mathrm{ml} /$ beat from before to after the use of polyprenols $(\mathrm{p}<0.05)$. The diastolic pressure (Pdia) decreased by $4 \mathrm{mmHg}$ for the $P U$, while it increased by $10 \mathrm{mmHg}$ in the $C(\mathrm{p}<0.05)$. The stroke volume $\left(S V_{c}\right)$ in the $P U$ increased by $2.9 \mathrm{ml}$, while that in the $C$ decreased by $7.4 \mathrm{ml}(\mathrm{p}<0.05)$. In conclusion, polyprenols improved oxygen consumption efficiency by increasing $\mathrm{SVc}$ and $\mathrm{O}_{2} / \mathrm{HR}$.
\end{abstract}

Key words: physical exercise, aerobic capacity, oxygen consumption.

\section{INTRODUCTION}

Polyprenols are linear polymers consisting of isoprene units, and they are found in almost all living bodies. For humans, the highest concentrations of polyprenols are in the pituitary gland and the testicles. Endogenous polyprenols are synthesised by the mevalonate pathway, and the pathway's beginning step coincides with that of cholesterol synthesis (Swiezewska et al., 2005).

It is known that polyprenols protect cell membranes from peroxidation and from reactive oxygen species that accumulate during physical exercise as well as in the ageing process (Bizzarri et al., 2003; Pallottini et al., 2003; Swiezewska et al., 2005). Isoprenoids and their phosphates in membrane models increase membrane permeability and improve membrane fusion. Their hepatoprotective abilities are described as well (Swiezewska et al., 2005; Yang et al., 2011). Polyprenols protect muscles from statin-induced muscle damage in rats by improving their muscle strength and power (Jansone et al., 2016). Similar effects were found in statin-using patients, for whom a combination of polyprenols and CoQ10 increased creatine phosphokinase (CFK) levels and improved muscle symptoms associated with statin-induced myopathy (Latkovskis et al., 2016). As most of the CFK found in the plasma is derived from skeletal muscle, it has been stated that polyprenols might have an impact on CFK activity. This impact could improve intracellular transport of energy and intensify ATP synthesis, which leads to the improvement of muscle-related symptoms.

Although recent studies recommend food supplementation only for individuals with dietary restrictions or deficiencies 
(Goston and Correia, 2010), the use of food supplements to improve athlete performance is very common (Mcdowall, 2007; Evans et al., 2012).

Polyprenol has stimulatory effects on the functional abilities of muscle and in the prevention of oxidative stress, which has been proven in different studies in response to the question of whether the intake of polyprenols can enhance athlete performance. We hypothesised that the use of polyprenols can improve aerobic capacity in amateur athletes. The aim of the study was to investigate possible polyprenol effects on athletic performance during maximal incremental veloergometric testing.

\section{METHODS}

Preparation of liposomal (Abies sibirica) polyprenol softgel capsules. Siberian fir (Abies sibirica) polyprenols (purity $\sim 80 \%$ ) were acquired from AS "Biolat" (Salaspils, Latvia), where they had been extracted according to the procedure described in the patent of Russian Federation No. RU 2259991 (Karpitskij and Koshkarev, 2005; Jozwiak et al., 2013). The phospholipid mixture Phosal 40 IP (contains at least $40 \%$ of soybean phosphatidylcholine) was purchased from "Lipoid" GmbH (Ludwigshafen, Germany). Polyprenol liposomes were prepared via a method based on the co-solubilisation and modified ethanol injection of polyprenols in an ethanol-phospholipid system (ratio of $\sim 1: 17$ w/w). The resulting multilamellar liposomes (vesicle size $\sim 1.36 \mu \mathrm{m}$ ) were further encapsulated into soft gelatin capsules by standardised techniques according to Good Manufacturing Practice. Each capsule that was produced had the following composition: a) $220 \mathrm{mg}$ dry shell (136.76 mg gelatin, $82.25 \mathrm{mg}$ glycerol, and $0.99 \mathrm{mg}$ iron oxide brown), b) $470 \mathrm{mg}$ Phosal $40 \mathrm{IP}$ and c) $30 \mathrm{mg}$ Abies sibirica polyprenols.

Study design and participants. A total of 30 floorball players from the Latvian Floorball Men's Highest League, $1^{\text {st }}$ League and $2^{\text {nd }}$ League teams, who had an average age of $23.2 \pm 10.8$ years, an average weight of $77.9 \pm 7.4 \mathrm{~kg}$ and an average height of $182.8 \pm 7.0 \mathrm{~cm}$, took part in the study. All of the participants played floorball for at least four years and had three to four training sessions per week and one to two games per week during the last season and in recent seasons. The individuals were randomly divided into the experimental and control groups, which included 16 participants and 14 participants, respectively. The experimental group took three capsules of $30 \mathrm{mg}$ polyprenol liposomes per capsule three times per day during $69 \pm 5$ days, and the control group received capsules without polyprenols. Four participants were excluded from the study due to injuries or to personal reasons. All of the excluded athletes were from the control group, and therefore results represented include ten athletes in control group.

All of the athletes involved in the study completed a questionnaire that provided information on possible illnesses and on the use of food supplements that might interfere with the results of the present study. No radical changes in athletes' diet were made during study.

This study was approved by the Research Ethics Committee of the Institute of Cardiology and Regenerative Medicine of the University of Latvia and performed according to the Declaration of Helsinki.

Data collection. The athlete performance observation and data collection occurred at the Laboratory of Sports Physiology of the Department of Human and Animal Physiology of the Faculty of Biology of University of Latvia from 22 September 2016 until 15 April 2017. All of the athletes involved in the study performed maximal incremental veloergometric testing.

Veloergometry test. The test was carried out on a veloergometer (Ergoline, ergoselect 100/200 GmbH, Bitz, Germany). At the beginning, five resting minutes were recorded. The test started with a load of $50 \mathrm{~W}$, which was incremented by $25 \mathrm{~W}$ every two minutes. The test was continued until the athlete reached exhaustion. During the test and five resting minutes before, a 12-lead electrocardiogram was recorded using a cardiopulmonary device (Masterscreen CPX CareFusion, San Diego, CA, USA). The gas analysis data (respiratory rate, respiration volume, oxygen consumption and carbon dioxide production, etc.), as well as the arterial oxygen saturation, heart rate (HR) and additional parameters, were recorded continuously. Arterial blood pressure was measured at the second minute of each load (Tango +, SunTech Medical, Morrisville, USA). During recovery, all of the abovementioned parameters were recorded, and the participants continued to work at a load of $50 \mathrm{~W}$ until they reached their initial heart rate and/or arterial blood pressure.

Statistical analysis. As the normality assumption was violated for some variables of interest $\left(\mathrm{O}_{2} / \mathrm{HR}, \mathrm{SVc}\right.$ and diastolic blood pressure $(p=0.055))$ the nonparametric test procedure was considered. For each variable of interest, between-within subjects ANOVA based on trimmed means was conducted to test for the significance of group-by-time interaction effect. The trimming proportion was $20 \%$. p-values less than 0.05 were considered as statistically significant. Comparison of the obtained results was made with the results given by parametric between-within subjects ANOVA. Statistical analysis was performed using R Statistical Software (version 4.0.3; R Foundation for Statistical Computing, Vienna, Austria). All values were expressed as mean \pm standard deviation.

\section{RESULTS}

The maximal oxygen consumption per mass kilogram is one of most valuable measures of aerobic capacity. The average $\mathrm{VO}_{2}$ peak and ventilation (VE) of the last minute of the testing of each participant were used in the data analysis. The $\mathrm{VO}_{2}$ peak increased in the polyprenol group by 2.8 $\mathrm{ml} / \mathrm{min} / \mathrm{kg}$, while it decreased by $0.04 \mathrm{ml} / \mathrm{min} / \mathrm{kg}$ in the con- 
trol group (Fig. 1A). The VE increased by $8.6 \mathrm{l} / \mathrm{min}$ in the polyprenol group and by $3.4 \mathrm{l} / \mathrm{min}$ in the control group (Fig. 1B).

Heart rate changes were analysed as follows: the average HR of the last test minute of the first test was calculated and compared with the same load minute of the second test. For example, if in the first test the participant reached $250 \mathrm{~W}$ and in the second test the participant reached $275 \mathrm{~W}$, then the last minute of the first test was compared with the minute of the second test when the load was $250 \mathrm{~W}$. In the polyprenol group, the HR decreased by $2 \mathrm{bpm}$, and in the control group, it increased by $1 \mathrm{bpm}$ (Fig. 1C). Oxygen pulse characterises the peripheral oxygen extraction. The average $\mathrm{O}_{2} / \mathrm{HR}$ of the last minute of testing of each participant was used in the data analysis. Before the use of capsules, the $\mathrm{O}_{2} / \mathrm{HR}$ in the control group was $19.7 \pm 1.7$ $\mathrm{ml} /$ beat and that in the polyprenol group was $18.7 \pm 1.7$ $\mathrm{ml} /$ beat. After the use of capsules, the $\mathrm{O}_{2} / \mathrm{HR}$ in the control group was $19.3 \pm 1.5$ and that in the polyprenol group was $19.5 \pm 1.2 \mathrm{ml} /$ beat. In the polyprenol group, the $\mathrm{O}_{2} / \mathrm{HR}$ increased by $0.9 \mathrm{ml} / \mathrm{beat}$, while in the control group, it decreased by $0.4 \mathrm{ml} /$ beat (Fig. 1D). Changes in the $\mathrm{O}_{2} / \mathrm{HR}$ were statistically significant $(p<0.05)$. Systolic and diastolic blood pressures were analysed in the same pattern as the HR. Psys in the control group increased by $8 \mathrm{mmHg}$, while that in the polyprenol group decreased by $4 \mathrm{mmHg}$
(Fig. 2A). In the control group, the Pdia was $67 \pm 9 \mathrm{mmHg}$ before the use of capsules, and it was $78 \pm 17 \mathrm{mmHg}$ after the use of capsules. The Pdia before and after the use of capsules in the polyprenol group were $68 \pm 10 \mathrm{mmHg}$ and $64 \pm 10 \mathrm{mmHg}$, respectively. The Pdia in the control group increased by $10 \mathrm{mmHg}$, while in the polyprenol group, it decreased by $4 \mathrm{mmHg}$ (Fig. 2B). Changes in the Pdia did not reach statistical significance $(p=0.072)$.

The average SVc and cardic output (QTc) of the last minute of testing of each participant was used in the data analysis. In the polyprenol group, the SVc was $124.8 \pm 13.8 \mathrm{ml}$ before the use of capsules and was $127.7 \pm 6.9 \mathrm{ml}$ after the use of capsules. In the control group, the SVc was $133.7 \pm 13.6$ $\mathrm{ml}$ and $126.3 \pm 9.0 \mathrm{ml}$ before and after the use of capsules, respectively. In the polyprenol group, the SVc increased by $2.9 \mathrm{ml}$, while in the control group, it decreased by $7.4 \mathrm{ml}$ (Fig. 2C), and these changes were statistically significant $(p<0.05)$. The QTc increased in the polyprenol group by $0.6 \mathrm{l} / \mathrm{min}$, while it decreased in the control group by 0.9 1/min (Fig. 2D).

The test duration included a five-minute resting period, and it was a test with an incrementing load until exhaustion, but one that did not include recovery. Before the use of capsules in the polyprenol and control groups, the test duration was $23.2 \pm 2.0$ minutes. In the control group, the test duration did not change, while in the polyprenol group, it increased
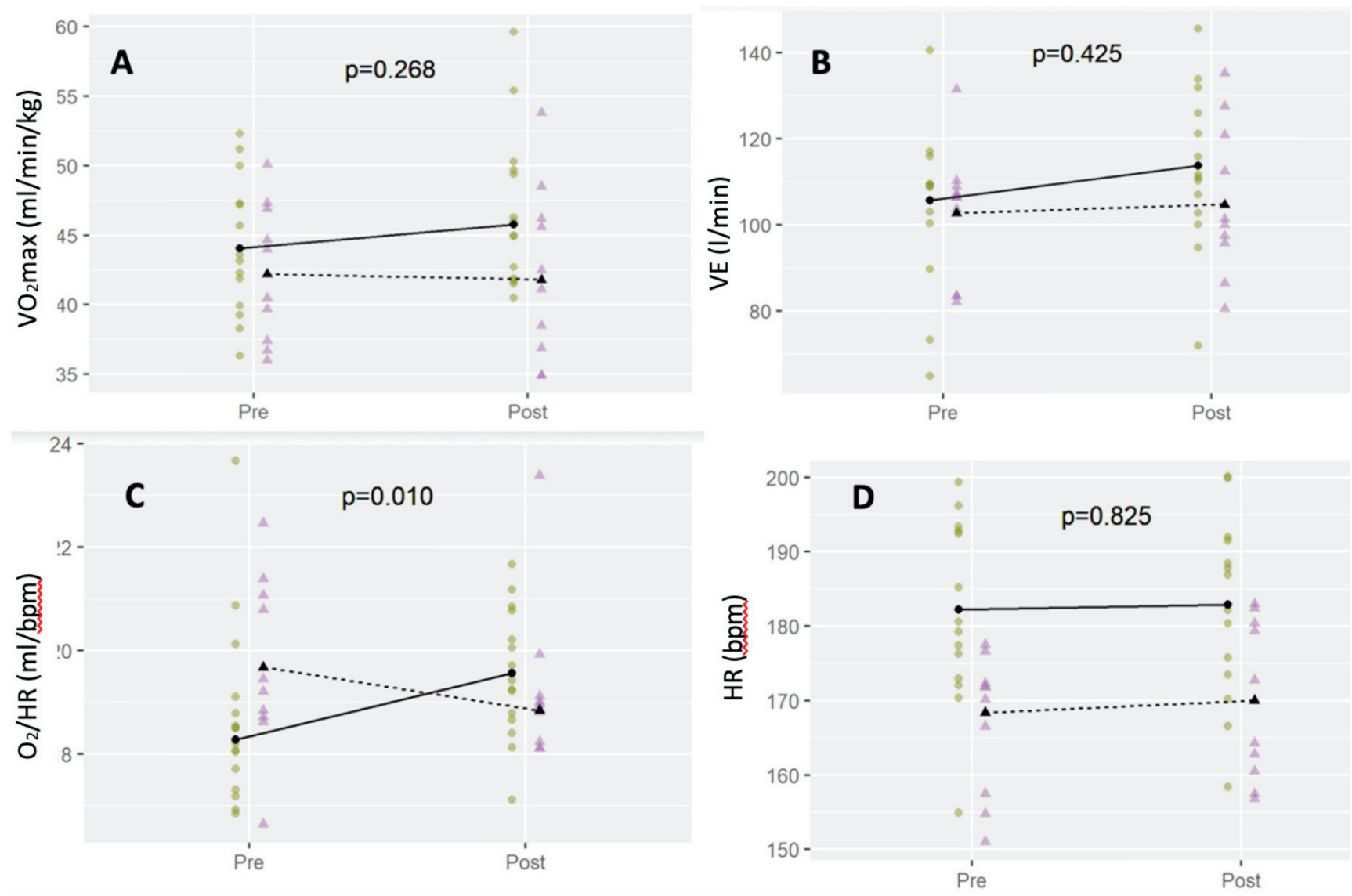

Fig. 1. Values of $\mathrm{VO}_{2}$ peak (A) (peak oxygen consumption, $\mathrm{ml} / \mathrm{min} / \mathrm{kg}$ ), VE (B) (ventilation, $1 / \mathrm{min}$ ), $\mathrm{HR}$ (C) (heart rate, beats per minute) $\mathrm{O}_{2} / \mathrm{HR}$ (D) (oxygen pulse, $\mathrm{ml}$ per beat) in the control (solid line) and polyprenol groups (dotted line) before (pre) and after (post) use of capsules. 

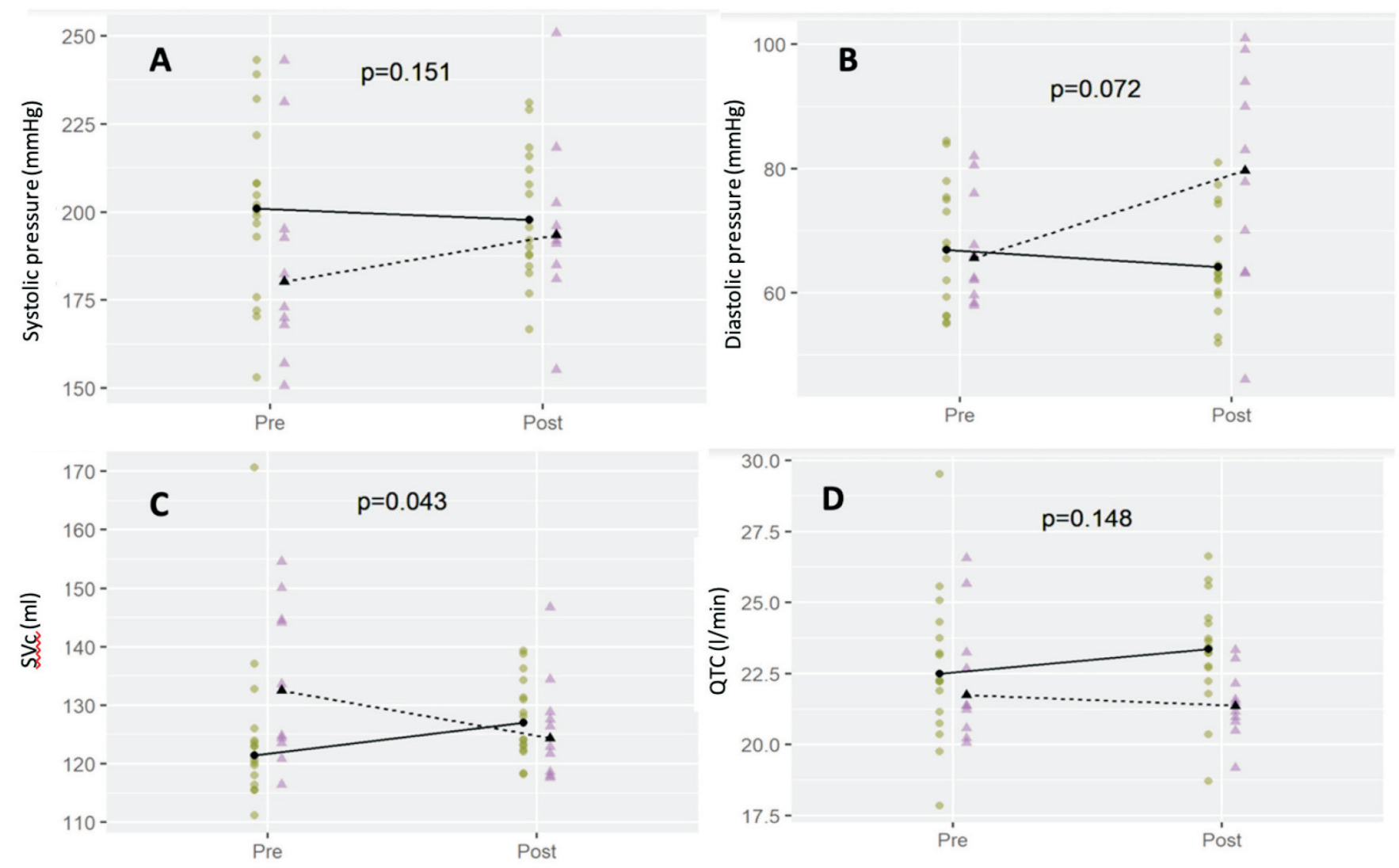

Fig. 2. Values of systolic blood pressure (A) (mmHg), diastolic blood pressure (mmHg) (B), SVc (C) (stroke volume, ml), QTc (D) (cardiac output, 1/min) in the control (solid line) and polyprenol groups (dotted line) before (pre) and after (post) use of capsules.

by 1 minute $(24.2 \pm 2.0$ minutes $)$, but changes were not statistically significant.

\section{DISCUSSION}

During the veloergometry test, various parameters were recorded. The most important ones are represented in the results, and it is seen that the use of polyprenol liposomes improves aerobic abilities compared with the control group. Indeed, the polyprenol users could perform the veloergometry test for one minute longer than the athletes from the control group. Although one minute appears to be an insignificant change in the test duration, it must be emphasised that the average duration of the veloergometry test in the control group was 23 minutes, and it reached a $250 \mathrm{~W}$ load, while in polyprenol user group, an average load of $275 \mathrm{~W}$ was reached at the $24^{\text {th }}$ test minute. This finding shows that polyprenol has a tendency to improve the ability to tolerate the high intensity exercise and that it could be valuable for on-field performance. For example, in floorball, which is a high-intensity interval sport, one shift lasts from 40 to 90 seconds, and in this case, one minute represents an important advantage.

The increase in the veloergometry test duration can be caused by various factors. One of the factors influencing physical abilities could be training during the season; one must note that in both the polyprenol user group and the control group, athletes were from the same team with the same training schedule. This factor excludes that differences between groups are caused by different training amounts and intensities. As described in the results, the $\mathrm{VO}_{2}$ peak, VE and QTc increased in the polyprenol user group, but these changes did not reach statistical significance. Statistically significant changes were seen in terms of $\mathrm{O}_{2} / \mathrm{HR}(p=0.010)$ and SVc $(p=0.043)$. Although these parameters are affected by diet, the immune system and other factors, they all improved after the use of polyprenolrich supplements and affirmed each other. This result shows that polyprenols increase aerobic capacity.

The increase in $\mathrm{VO}_{2}$ peak is natural if the test duration is longer. It has been stated that oxygen consumption increases with an increase in exercise intensity, until it reaches the individual's maximum (Bassett and Howley, 2000). $\mathrm{VO}_{2}$ peak depends on the lung capacity, and increases in VE affirm the reliability of the result.

One of the most important parameters in sports physiology is the $\mathrm{O}_{2} / \mathrm{HR}$, which describes the amount of oxygen in one heartbeat. Oxygen pulse represents peripheral oxygen extraction and, as seen in the results, it increased after the use of polyprenol-rich products in the polyprenol user group compared with the control group. These changes were statistically significant. As HR did not change after use of polyprenol-rich supplements, the increase in $\mathrm{O}_{2} / \mathrm{HR}$ is associated with improved peripheral oxygen extraction. The ef- 
fects of polyprenols on sportsman physical abilities have never been studied before; therefore, we suggest that polyprenols can stabilise cell membranes and can protect from peroxidation and oxidative stress (Bizzarri. et al., 2003; Pallottini et al., 2003). As the efficacy of $\mathrm{O}_{2}$ use relies on membrane permeability in muscle and alveoli, polyprenols might also have taken part in these processes. Moreover, similar effects of polyprenols in membrane models have been shown (Valtersson et al., 1985; Swiezewska et al., 2005). Levels of pro-inflammatory cytokines increase during intensive exercise, and polyprenols as antioxidants can improve cell membrane functions by suppressing the activity of lipoxygenase (Bonnans and Levy, 2007), thereby increasing the efficacy of oxygen use.

Arterial blood pressure is a significant parameter of physical ability. We observed that in the polyprenol user group, systolic and diastolic blood pressure decreased in comparison with that in the control group. Although these changes did not reach statistical significance, tendencies must be taken into account, and further studies should be carried out. The changes in blood pressure represented in the results might be linked to the increased efficacy of oxygen use and the increase in heart stroke volume. These positive changes in blood pressure after the use of polyprenols show the increased ability to tolerate high intensity exercise until exhaustion occurs. The increase in QTc is linked to the increase in stroke volume and oxygen extraction abilities as well.

\section{CONCLUSIONS}

Overall, these results show an increase in the aerobic capacity in the polyprenol user group compared with control group. Since previous studies on possible mechanisms include cell membrane models and animal studies as well as a few clinical studies, further evaluation of the polyprenol effects in human beings, including the effects on athlete performance, is needed; in addition, studies on the precise mechanisms of polyprenols in exercise performance are recommended.

\section{AUTHOR CONTRIBUTIONS}

The study was designed by LU, LP, IV, UK; data were collected and analysed by LU, LP, KK, data interpretation and manuscript preparation were undertaken by BJ, RM, LU, LP, IV. All authors approved the final version of the paper.

\section{CONFLICT OF INTERESTS}

The results of the current study do not constitute endorsement of the product by any of the authors.

\section{ACKNOWLEDGMENTS}

This study was conducted with support from the European Regional Development Fund (ERDF) within the framework of the project "Competence center of smart materials and technologies" in accordance with the contract No. 1.2.1.1/16/A/005 between "'Competence center of smart materials and technologies" Ltd. and the Central Finance and Contracting Agency, concluded on 26 September 2016. I. Vanaga and U. Klētnieks are employed at "Silv EXPO”, LTD.

\section{REFERENCES}

Bassett, D. R., Howley, E. T. (2000). Limiting factors for maximum oxygen uptake and determinants of endurance performance. Med. Sci. Sports Exerc., 32 (1), 70-84.

Bizzarri, R., Cerbai, B., Signori, F., Solaro, R., Bergamini, E., Tamburini, I., Chiellini, E.. (2003). New perspectives for (S)-dolichol and (S)-nor dolichol synthesis and biological functions. Biogerontology, 4 (6), 353-363.

Bonnans, C., Levy, B. D. (2007). Lipid mediators as agonists for the resolution of acute lung inflammation and injury. Amer. J. Respir. Cell Mol. Biol., 36 (2), 201-205.

Evans, M. W., Ndetan, H., Perko, M., Williams, R., Walker, C. (2012). Dietary supplement use by children and adolescents in the United States to enhance sport performance: results of the National Health Interview Survey. J. Prim. Prev., 33 (1), 3-12.

Goston, J. L., Correia, M. I. (2010). Intake of nutritional supplements among people exercising in gyms and influencing factors. Nutrition, 26 (6), 604-611.

Jansone, B., Dzirkale, Z., Jekabsons, K., Pilipenko, V., Beitnere, U., Māgure, I., Skumbiņ̌̌, R., Klētnieks, U., Vanaga, I., Muceniece, R., Kluša, V. (2016). Spruce needle polyprenols protect against atorvastatin-induced muscle weakness and do not influence central nervous system functions in rats. Proc. Latvian Acad. Sci., Section B, 70 (1), 13-20.

Jozwiak, A., Brzozowski, R., Bujnowski, Z., Chojnacki, T., Swiezewska, E., (2013). Application of supercritical $\mathrm{CO}_{2}$ for extraction of polyisoprenoid alcohols and their esters from plant tissues. J. Lipid Res., 54, 2023-2028.

Karpitskij, V. I., Koshkarev, I. M. (2005). Method for preparing polyprenols [Карпицкий, В. И., Кошкарев, И. М. Способ получения полипренолов]. Patent of Russian Federation No. RU 2259991(in Russian).

Latkovskis, G., Saripo, V., Sokolova, E., Upite, D., Vanaga, I., Kletnieks, U., Erglis, A. (2016). Pilot study of safety and efficacy of polyprenols in combination with coenzyme Q10 in patients with statin-induced myopathy. Medicina (Lithuania), 52 (3), 171-179.

Mcdowall, J. A. (2007). Supplement use by young athletes. J. Sports Sci. Med., 6, 337-342.

Pallottini, V., Marino, M., Cavallini, G., Bergamini, E., Trentalance, A. (2003). Age-related changes of isoprenoid biosynthesis in rat liver and brain. Biogerontology, 4 (6), 371-378.

Swiezewska, E., Danikiewicz, W. (2005). Polyisoprenoids: Structure, biosynthesis and function. Prog. Lipid Res., 44 (4), 235-258.

Valtersson, C., Duyn, G. van, Verkleij, A. J., Chojnacki, T., de Kruijff, B., Dallner, G. (1985). The influence of dolichol, dolichol esters, and dolichyl phosphate on phospholipid polymorphism and fluidity in model membranes, J. Biol. Chem., 260 (5), 2742-2751.

Yang, L., Wang, C. Z., Ye, J. Z., Li, H. T. (2011). Hepatoprotective effects of polyprenols from Ginkgo biloba L. leaves on CCl4-induced hepatotoxicity in rats. Fitoterapia, 82 (6), 834-840. 


\section{POLIPRONOLU LIPOSOMAS PALIELINA SKĀBEKL̨A IZMANTOŠANAS EFEKTIVITĀTI LABI TRENĒTIEM AMATIERIEM VĪRIEŠIEM}

Poliprenoli ir lineāri polimēri, kas sastopami gandrīz visos dzīvajos organismos, un ir zināms, ka tie pasargā šūnu membrānas no peroksidācijas (brīvajiem skābekḷa radikāliem), kas notiek novecošanās procesa vai fiziskas slodzes laikā. Tāpat ir zināms, ka poliprenolu lietošana mazina statīnu izraisītu muskuļu vājumu, tomēr līdz šim nav pētīta poliprenolu ietekme uz sportistu fiziskajām spējām. Pētîjuma mērkis ir noskaidrot poliprenolu ietekmi uz fiziskajām spējām labi trenētiem vīriešiem. Pētījumā piedalījās 30 florbolisti, no kuriem 16 lietoja kapsulas, kas satur $30 \mathrm{mg}$ poliprenolu, bet 14 lietoja kapsulas bez poliprenoliem $69 \pm 5$ dienas. Visas pētījumā iesaistītās personas veica maksimālas pieaugošas kāpṇveida slodzes veloergometrijas testu pirms un pēc kapsulu lietošanas, kura laikā tika noteikts $\mathrm{VO}_{2} \mathrm{max}$ (maksimālais skābekḷa patēriņš) un citi kardiorespiratorās sistēmas parametri. Poliprenolu lietotāju grupā (PG) skābekḷa pulss palielinājās par 0,9 ml/sitienu, savukārt kontroles grupā $(K G)$ tas samazinājās par $0,4 \mathrm{ml} /$ sitienu $(p<0.05)$. Diastoliskais spiediens PG samazinājās par $4 \mathrm{mmHg}$, bet palielinājās par $10 \mathrm{mmHg} \mathrm{KG}(p<0.05)$, savukārt sirds izsviedes tilpums PG palielinājās par 2,9 ml, bet KG samazinājās par $7,4 \mathrm{ml}(p<0.05)$. Vidējais veloergometrijas slodzes laiks PG palielinājās par vienu minūti, bet tas nemainījās KG. Kopumā poliprenoli uzlabo skābekḷa izmantošanu, palielinot skābekḷa pulsu un sirds izsviedi. 